\title{
Papillary carcinoma in thyroglossal duct cyst: A case report
}

\section{Tiroglossal Kanal Kistinde İnce lğne Aspirasyon Biopsisi llle Tanımlanan Papiller Karsinom}

\author{
Güllay Cetinn ${ }^{1}$, İsmaill Șallk², Reyhan $\mathbb{E}_{\text {ğillmez }}^{3}$
}

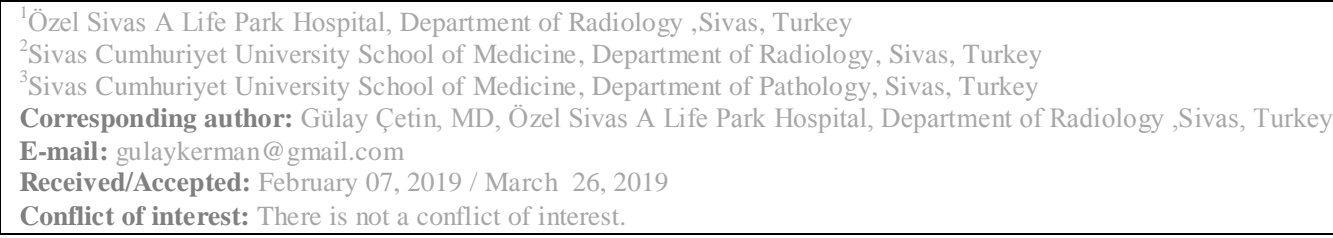

\section{SUMMARY}

Thyroglossal duct cysts (TDC) are the most common congenital neck cysts and malignancy can be seen in $1 \%$ of the cases. The most common malignant pathology of the thyroid is papillary carcinoma. Pathological examination is necessary for diagnosis and planning of the treatment. In this study, we reported a 42 -year-old male patient who has a $17 \times 15 \mathrm{~mm}$ diameter TDC in the midline and he was treated with transcervical excision after US-guided fine needle aspiration biopsy (FNAB) from the solid lesion.

Keywords: Thyroglossal duct cyst, neck cyst, papillary carcinoma.

\section{ÖZET}

Konjenital boyun kistlerinden en sık karşılaşılan tiroglossal kanal kistidir (TKK) ve \%1 oranında malignite görülebilir. En sık görülen malign patoloji, tiroidin papiller karsinomasıdır. Tedavinin planlanması ve tanı için patolojik inceleme gereklidir. Burada, boyun orta hat yerleşimli, 17x15 mm çaplı TKK' i olan, içerisindeki solid lezyondan US eşliğinde ince iğne aspirasyon biopsisi (İ̈AB) ve sonrasında transservikal eksizyon ile tedavi edilen 42 yaşında erkek hasta sunuldu.

Anahtar sözcükler: Tiroglossal kanal kisti,boyun kistleri,papiller karsinom

\section{INTRODUCTION}

Thyroglossal duct cyst (TDC) is a congenital disorder of thyroglossal canal residues and occurs at $7 \%$ of young adults.

It is commonly seen in the anterior-midline of the neck and constitutes $40 \%$ of the neck masses except for the neck masses evolved from lymphatic origin ${ }^{1}$. The development of carcinoma is substantially rare and observed in $1 \%$ of cases ${ }^{2}$, 3. Although the first cases were reported by Bredano in 1911 and by Uchermann in 1915, less than 200 cases had been recorded since then ${ }^{4-6}$. In spite of there are no comprehensive series in the literature; Ortiz et al. ${ }^{7}$ reported five cases, and Miccoli et al ${ }^{8}$ reported 18 case series in their studies. Most of the cases were clinically defined as thyroglossal duct cysts and the malignancy was revealed by histological study of the excised surgical specimen, casually. In the study of Miccoli et al . ${ }^{8}$, Half of the cases $(50 \%)$ were diagnosed postoperatively.

In this study, we present a patient who was diagnosed as papillary carcinoma with FNAB (fine needle aspiration biopsy) in the thyroglossal duct cyst and was shown the accuracy of this pathology after surgery.

\section{CASE REPORT}

A 42-year-old male patient operated because of a painless neck swelling that he noticed one month ago. There was not any radiation history to the neck or any part of the body. The patient, who has localized a swelling about $2 \mathrm{~cm}$ in diameter to the midline of the neck referred to the radiology clinic 
for ultrasound examination to investigate the thyroglossal cyst or mass etiology. The ultrasound examination of the neck region was reported as; a mass lesion of approximately $17 \times 15 \mathrm{~mm}$ with no visible vascular Doppler activity in the midline neck muscles, partially mobile with swallow, independent of the thyroid gland, well-defined, heterogeneous and solid character was detected (Figure 1). The thyroid gland was of normal size, and no nodules were detected by ultrasonography. Additionally, there was no cervical lymphadenopathy in terms of pathological dimension and character.

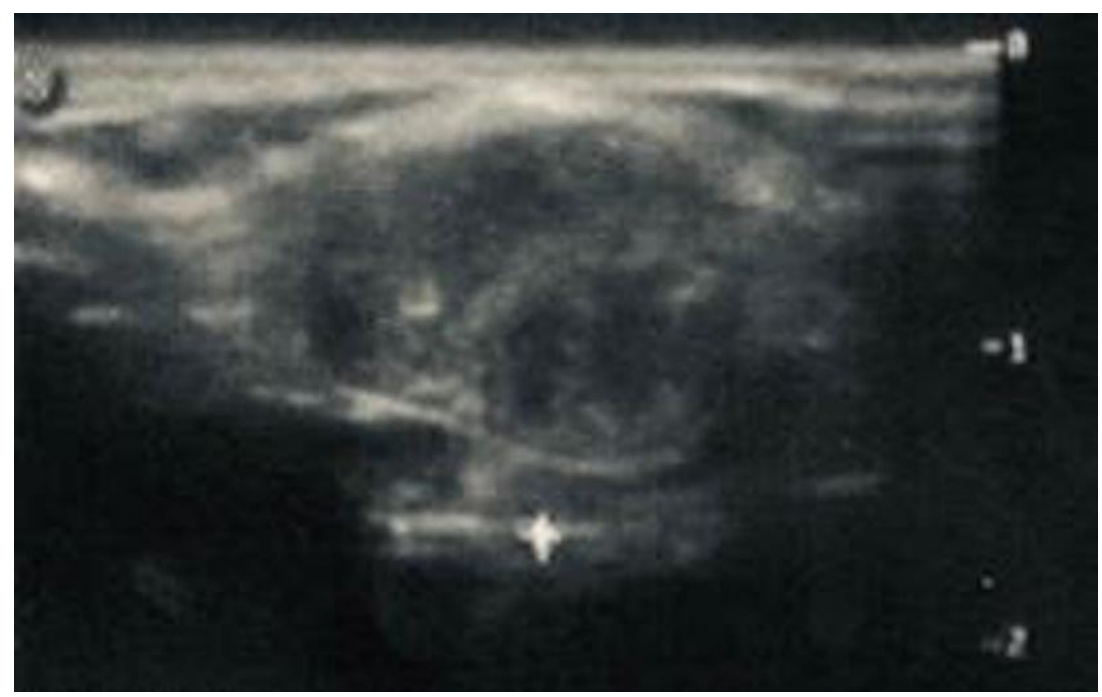

Figure 1. In the neck ultrasonography, a mass was partially well-defined, heterogeneous and approximately $17 \times 15 \mathrm{~mm}$ size was seen in the midline.

FNAB (fine needle aspiration biopsy) was recommended to the patient, considering sonographic findings of a dense thyroglossal cystmalignant mass lesion. Ultrasound-guided FNAB was reported by pathology as " malignancy + compatible with papillary carcinoma developing based on thyroglossal cyst ". After total thyroidectomy and mass excision, the pathology result was papillary carcinoma of the thyroid gland based on thyroglossal cyst without angiolymphatic invasion, without capsular and extracapsular extension (Figure 2). In addition, total thyroidectomy material was evaluated as diffuse hyperplasia.

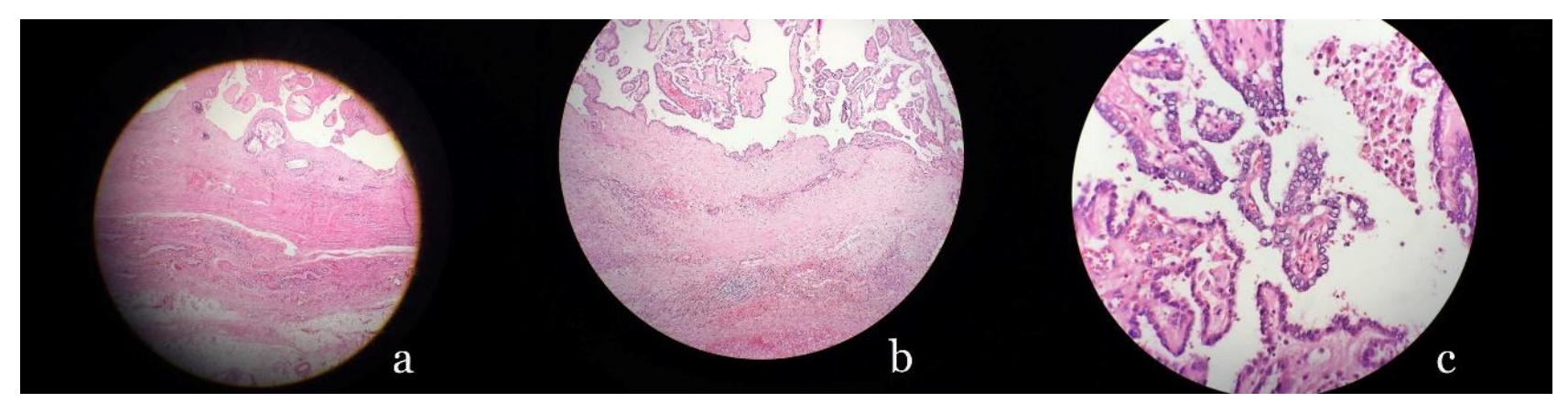

Figure 2. a. Papillary carcinoma of thyroid, including thick capsule with continued fat tissue (H\&E, $\mathrm{x} 40)$, b. Papillary carcinoma with thick capsule containing lymphoid aggregat $(\mathrm{H} \& \mathrm{E}, \mathrm{x} 40)$, and c. Tumor cells with large ground glass nucleus, showing crowded, prominent of nuclear membrane, and aligned around the fibrovascular stroma (H\&E,x80). 


\section{DISCUSSION}

The thyroid gland is the first endocrine gland developing on the twenty-fourth day of embryogenesis. After rising through the foramen caecum at the base of the tongue it takes its normal position by migrating downward to the midline. Normally, the channel regresses spontaneously, but rarely persists. Thyroglossal duct cyst may be consisted by dilating the persisting channel. Generally, the cyst is detected by chance on physical examination performed for other reasons. Because of its rarity, malignancy is not suspected before surgical excision. Patients usually admit to the outpatient clinic due to a palpable mass which is not inclined expanding.

As in the presented case, most masses are detected in the midline on physical examination.It is but rarely localized on the lateral side ${ }^{2,9}$. Elderly patients, female patients and patients with a rapid increase of size of the lesion are at higher risk for malignancy ${ }^{10}$. Two types of histological types have been described; the first and often seen origin from the thyroid components, the second origin from squamous components.

The cases of $80 \%$ of papillary carcinoma, $9 \%$ of mixed papillary and follicular carcinoma, $7 \%$ of squamous carcinoma, $2 \%$ of adenocarcinoma, $1 \%$ follicular carcinoma, and $1 \%$ of anaplastic carcinoma are reported ${ }^{11-13}$. In this case, we detected papillary carcinoma.

When TDC is detect in an adult person, the thyroid and neck lymph nodes should be examine by ultrasonography ${ }^{7}$. Treatment of malignant lesions originated from TDC is clear. The removal of the thyroglossal tract is the standard procedure, but the surgical method in tumoral spread is variable ${ }^{14,15}$.

Up to $95 \%$ curative ratio is reported in develop from TDC papillary carcinoma with Sistrunk operation method ${ }^{5}$. Various hypotheses have been proposed in the development of this malignancy. In one of these cases, because of the presence of squamous epithelium, a carcinoma that develops from here will be a squamous type, and only papillary carcinoma may be metastasized to the primary lesion in the thyroid gland, and the necessity of total thyroidectomy is highlighted ${ }^{16}$, 17 .

However, in the presented case, total thyroidectomy specimen had no malign cells. Miccoli et al. ${ }^{8}$ found the presence of thyroid malignancy in 6 of 18 cases of papillary carcinoma that originated from TDC. In addition,
I-131 scintigraphy and thyroglobulin levels can be used for recurrence follow-up ${ }^{12}$. Following the Sistrunk procedure, postoperative follow-up to patients with total troidectomy should be performed in terms of permanent and effective treatment ${ }^{8}$. The prognosis of papillary carcinoma from TDC may be similar and better with the thyroid gland malignancies ${ }^{11,18}$. As a result, neck midline masses determined by examination should be evaluated by ultrasonography and FNAB should be apply by guiding ultrasonography and medical and surgical treatment should be decide according to the results.

\section{REFERENCES}

1. Vincent S, Synhorst II J. Adenocarcinoma arising in a thyroglossal duct cyst. J. Oral Maxillofac Surg. 1989; 47: 633- 635.

2. Allard R. The thyroglossal cyst. Head Neck Surg 1982;5: 134- 146.

3. Fernandez J, Ordonez N, Shultz P, Samaan N, Hickey R. Thyroglossal duct carcinoma. Surgery 1991; 110: 928-935.

4. Walton B,Koch K. Presentation and management of thyroglossal duct cyst with a papillary carcinoma. South Med J 1997; 90: 758- 761.

5. Jaques D,Chambers R,Oertel J. Thyroglossal tract carcinoma. Am J Surg. 1970; 120: 439446.

6. Roses D, Snively S, Phelps R, Cohen N,Blum M. Carcinoma of the Thyroglossal Duct. Am J Surg 1983; 145: 166-169.

7. Luna-Ortiz $\mathrm{K}$, Hurtado-Lopez LM, Valderrama-Landaeta JL, Ruiz-Vega A. Thyroglossal duct cyst with papillary carcinoma: what must be done? Thyroid 2004; 14: 363-366

8. Miccoli P, Minuto MN, Galleri D, Puccini M, Berti P. Thyroid 2004; 14: 121-123

9. Pollock WF. Cysts and sinuses of the thyroglossal duct. Am J Surg 1966; 122: 225 229.

10. Topf P,Fried M,Strome M. Vagaries of thyroglossal duct cysts. Laryngoscope 1988; 98. 40-42.

11. LiVolsi VA, Perzin KH, Satevsky L. Ectopic thyroid (including thyroglossal duct tissue) Cancer 1974;34: 1303-1315.

12. McNicol MD, Hawkins DB, Peny Rand Maceri 
RD. Palillary carcinoma arising in thyroglossal duct cysts. Otolaryngology- Head and Neck Surgery. 1988;99: 50-54.

13. Trail ML, Zerique GP, Chicola J. Carcinoma in thyroglossal duct remnants. Laryngoscope. 1977;87: 1685-1691.

14. Larquare MJ, Drake AF, Baker SR, Richter HJ, Magieski JE. Evaluation and management of carcinoma arising in a thyroglossal duct cyst. Am J Otolaryngol. 1987;8: 351-355.

15. Morris RM, Woody AE. A closer look at the thyroglossal cysts. Ear, Nose and Throat Journal. 1987;66: 40-45.
16. Judd ES. Thyroglossal duct cyst and sinuses. Sur Clin North AM. 1963;43: 1023-1032.

17. Nuttall FQ. Cystic metastases from papillary adenocarcinoma of thyroid with comments concerning carcinoma associated with thyroglossal remnants. Am J Surg 1965;109: 500-505.

18. Bhagavan VS, Rao DR, Weinberg $T$. Carcinoma of thyroglossal duct cyst: case report and review of literature. Surgery. 1970;67: 281-292. 